\title{
Maturity Assesment: A Case of Micro and Small Service Enterprises
}

\author{
Blanca, Carballo-Mendivil, PhD \\ Alejandro, Arellano-Gonzalez, PhD \\ Nidia Josefina, Ríos-Vazquez, PhD \\ Sonora Institute of Technology, Mexico
}

doi: 10.19044/esj.2017.v13n16p49 URL:http://dx.doi.org/10.19044/esj.2017.v13n16p49

\begin{abstract}
High percentages of Micro and Small-sized enterprises (MSEs) perish in their initials years of business. That is why various efforts have been made to know their operation and improve it. However those proposals of improvement are mostly based in reductionist diagnostics that limit the understanding of their business processes. This paper presents an integral diagnostic of MSEs, specifically in the service sector in the north of Mexico, through which the maturity level of its processes is determined. The design was descriptive exploratory with a quantitative approach. A rubric-type instrument was applied, which was designed to perform an integral diagnosis and measure the maturity level of the processes in 140 companies. The results indicate that the maturity levels of the business processes in the service sector are mostly craft-like. The elements with the lowest maturity levels include service assessment as part of management, the capacity to design new services/processes, evaluation and selection of suppliers, and improvements to the purchasing process that can assure an appropriate level of service. The need to implement improvement projects in areas related to planning, monitoring, control and information support systems were also detected. The main contribution of this work is having defined the service sector of the municipality where the organizations under study are located, which will help entrepreneurs in the sector, to improve their knowledge on the area in which they operate; researchers decide to make more contributions to the sector; and clients obtain information about the business they purchase from.
\end{abstract}

Keywords: Maturity diagnostic, processes, service sector 


\section{Introduction}

Services represent around two-thirds of global economic production and are positively associated with per capita income, being the most promising economic sector. This is corroborated by the statistics presented by the World Bank, which reports that it is the only sector that increased its percentage of participation in Gross Domestic Product from 2000 to 2015, as shown in Figure 1 (World Bank Group, 2016).

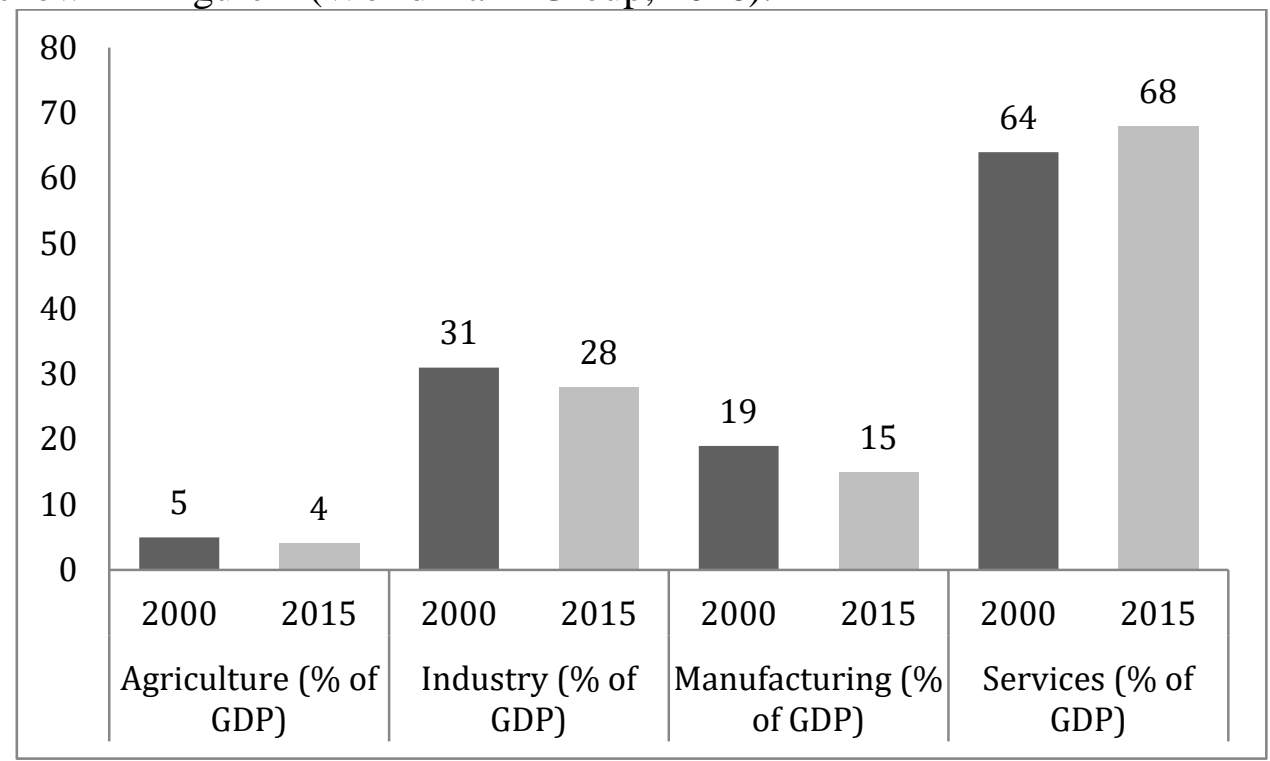

Figure 1. Percentage of global GDP growth by sector

Source: Prepared by the authors based on data from the World Bank Group (2016)

In the region of Latin America and the Caribbean, for example, this sector employs $52 \%$ of the male population and $79 \%$ of the female population (World Bank Group, 2016). In Mexico particularly, 49.5\% of the country's inhabitants work in this sector (Instituto Nacional de Geografía y Estadística - INEGI, 2014). (The National Institute of Statistics and Geography)

According to INEGI (2014), there are 1,889,147 companies classified in the private non-financial service sector in Mexico, of which $95.8 \%$ employ 10 people or fewer, while the other 3\% have between 11 and 50 employees; that is, 99.4\% can be defined as micro and small enterprises (MSEs), according to the Diario Oficial de la Federación - DOF (Official Journal of the Federation) (2009).

In the global environment, MSEs, especially those in the service sector, have been relegated to playing a minor role in the economy, as attention has been focused on industrialization and mass production. Nevertheless, over the years, governments as well as educational institutions and consulting centers have found that these companies have great potential 
and that proper administration could imply a drive toward economic development in a country such as Mexico, as they generate $74 \%$ of total employment.

However, statistics presented by INEGI (2014) show that 32\% of companies in Mexico, specifically in the service sector, perish in their first year of business, and by the fifth year, this percentage increases to 64\%, i.e., of ten business that begin operating today, only three or four will remain open for five years.

The above has prompted research to know the functioning of MSEs, to strengthen them and prolong their life in the market, as in the research carried out by the PYMES-Cumex Network (SME Network-Consortium for Mexican Universities) (2010) on a group of companies from the states of Mexico, Hidalgo, Puebla, Sonora, and Tamaulipas, in which financial and administrative profiles were compared to identify their problems, finding that the majority of these companies have an accounting system and make decisions based on this kind of information, but that their administrative profile shows that planning is one aspect that still needs work, as an average of only $47 \%$ of the companies indicate that they make plans. Nonetheless, only $17 \%$ have documented their plans, which indicates a problem: small businesses generally do not plan, despite concerning themselves with maintaining a formal organizational structure (organigram, procedures and functions manual). Likewise, the information technology they use is incipient and lagging far behind the modern techniques for communicating information with clients and suppliers.

Particularly, in one of the municipalities of Sonora, Cajeme, where the $98.4 \%$ of the companies are MSE (INEGI, 2014), the research conducted by Landázuri-Aguilera, Chávez-Rivera, and Ochoa-Jaime (2013) warn that the business is an image of the owner or the decision maker in these organizations, and consequently, research has been carried out that allows profiling this person. They indicate that the entrepreneur in Cajeme are persons who have had the opportunity to study higher education such as high-school, a technical degree, and a bachelor's, regardless of the urban area, and that they have been perseverant in the business they started and have not abandoned it to change their activities or projects.

Likewise, regarding the investment made in tangible resources, these authors identify that only $4 \%$ of owners acknowledge having made a large investment into their companies in the last three years; however, those with more time in the business acknowledge having made low, medium, and even no investment, which indicates that although the problems are similar, it is possible that the needs are not the same for all businesses, but rather depend on the level in the lifecycle they are currently in, as explained by Adizes (1994), or on their degree of organizational maturity. 
On this latter point, diagnostic studies have also been carried out to determine the maturity level of regional companies with a focus on process maturity, as reported by Arellano-González, Carballo-Mendívil, OrrantiaLópez, and Salazar-Rivera (2013), who report the case of a small Mexican industrial business, where a rubric was applied to evaluate the maturity of their value chain processes, placing the company at maturity level II (proactive) out of four defined levels of maturity, and improvement projects were proposed according to said maturity state to begin a gradual change, developing strategies that reinforce the processes with a lower level of development.

This is considered a good approach to addressing the problem of MSEs in the municipality of Cajeme and its surrounding areas, since knowing the maturity level of each process will allow guiding improvement projects appropriate for specific characteristics and needs. Consequently, the aim is to determine the maturity level of organizational processes in small service businesses in the municipality of Cajeme, with the purpose of identifying areas of improvement that promote a shift toward a higher state of maturity.

\section{Theoretical foundation}

In the business and academic world, scholars in the areas of management and evaluation have proposed diverse internationally renowned reference models, useful for carrying out diagnostic studies, such as the models of excellence, including the European Foundation for Quality Management (EFQM) Excellence Model (2012), the Malcolm Baldrige from the United States, the Deming from Japan, and Mexico's Model for Competitiveness. In the scientific literature, several application cases of these models in small businesses in diverse countries are presented, such as The European Union (Tarí-Guilló, López-Gamero, \& Molina-Azorín, 2007), Colombia (Parra, Villa, \& Restrepo, 2009), and Cuba (González-Solá, A., \& Vilalta-Alonso, 2007), among others. Likewise, evaluation methodologies proposed by researchers to perform analyses on small businesses can be found, for example, that presented by Rohvein, Paravie, Urrutia, Roark, Nunes, and Ottogalli (2013) for evaluating the competitiveness level of SMEs based on two different approaches: one on activities and the other on resources.

Additionally, organizational and process maturity models are reported in the literature, understood as the real possibility of an organization to learn and use knowledge acquired over time in a manner that allows it to become an increasingly successful business (Röglinger, Pöppelbuß, \& Becker, 2012; Montaño-Arango, Corona-Armenta, Pérez-Rojas, \& MedinaMarin, 2010; Montaño-Arango, 2012; Brookes, Butler, Dey \& Clark 2014; 
Carroll \& Helfert, 2015; Mullaly, 2014; Kosieradzka, 2017; Butzer, Schötz \& Steinhilper, 2017; Proença \& Borbinha 2016; Domingues, Sampaio \& Arezes, 2016; Tarhan, Turetken \& Reijers, 2016; Uskarc1 \& Demirörs, 2017; Oliva, 2016; von Scheel, von Rosing, Skurzak \& Hove, 2015, entre otros). A model of these characteristics reports different maturity levels that express criteria with the purpose of guiding actions through the implementation of good practices in terms of operation and management. Some of the authors that propose maturity models, besides Montaño-Arango et al. (2010), are Hammer (2007), the International Organization for Standardization (2009), Software Engineering Institute (2010), and Arellano-González, CarballoMendívil y Ríos-Vázquez (2017).

Maturity models not only allow implementing diagnostics to identify an organization's problematic situation, but also, before quantifying gaps or opportunity areas for improvement in the company, consider the organization's maturity level, and with that, the measures that derive from true development.

When developing diagnostic studies, it is also important to consider the characteristic of the sector under study. Thus, specific models of service sector company processes have been developed, such as that presented by Arellano-González, Carballo-Mendívil, and Ríos-Vázquez (2017) known as the Organizational Performance Architecture of Service Businesses (ADOES, for its acronym in Spanish), presented in Figure 2.

The ADOES model was designed with a focus on systems, including the following elements from the ADOES model: environment, clients, competitors, suppliers, and processes, where internationally accepted as ideal such as the Porter's supply chain morphology (2005), the SCOR model proposed by the Supply Chain Council (2010), and the PDCA philosophy for process management included in the ISO 9001 model (2015).

In accordance with this work approach by processes, different types of processes are found in any organization, which are normally classified as follows:

\section{Strategic processes}

These are to give governance and direction to the organization, and include: strategic planning through which the organization can establish a long-term vision and strategies to realize this vision (Porter, 2005); organizational management, which refers to the traditional activities of tactical and operational planning, organization, management, and control; and the management of comprehensive systems that allow organizational quality and excellence through an appropriate focus on processes oriented toward the customer, external relations management, and orientation toward improved performance, as suggested by ISO (2015). 


\section{Key processes}

These are the main links in the chain, through which value is added to the client. In service businesses, these include processes such as service delivery planning, marketing and sales, the development of service delivery operations, and after-sales customer service management (Porter, 2005).

\section{Support processes}

These provide support to those activities directly related to customer satisfaction. According to Arellano-González et al. (2017), two kinds of support processes can be found in a business: a) those that support the key processes, known as key support, which ensure that there are the necessary resources to be able to provide the service and have a positive impact on customer satisfaction, such as research and development, inventory supply and management, and infrastructure management; and b) administrative support processes, which support the remaining processes in order to carry out all the operations that allow the company to function, such as the management of human, material, financial, infrastructure, and technological resources.

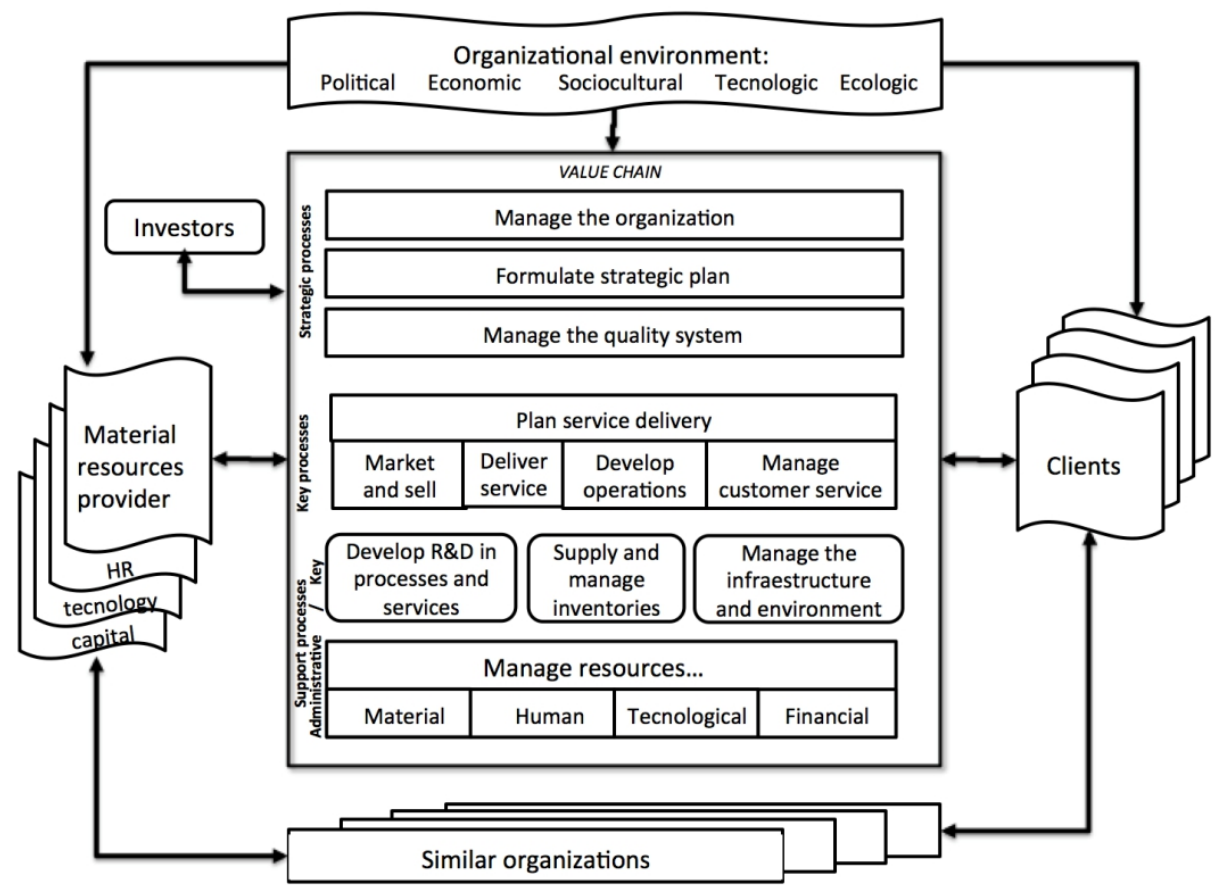

Figure 2. Organizational Performance Architecture of a Service Business (ADOES) Source: Arellano-González, et al. (2017).

Likewise, as explained in Arellano-González et al. (2017), this model considers that the processes go through several levels toward maturity. The lowest level is Incipient, where there is little knowledge of good practices, 
which makes developing improvement impossible. When this level is passed, the company becomes Craft-like, where it now has general knowledge of the continuous improvement approach, but has neither formalized nor systemized, although it does sporadically implement improvement activities. The next level is when the company passes to the Developing stage, where the processes are systematically managed with orientation toward continuous improvement in the use of metrics in the majority of the links in the chain. And finally, a company is considered to be in a Mature state when it has defined processed with a focus on innovation that is pervasive in all links of the chain (internal and external), in addition to being renowned as a leader in the market.

\section{Method}

The method followed to perform the analysis of the current situation of the system under study was based on the logic of the Gap Analysis, where a comparison is made between the real situation of the organization and an ideal established in a reference model, in this case, the ADOES model, whose advantage is that it not only allows identifying areas of opportunity for improvement in the company, but also considers beforehand the maturity level of the organization, so that the established improvement actions are not reductionist, attending only to minor problems and overlooking situations that interfere with development.

\section{Participants}

The subject under study in this research is the small service sector business from the municipality of Cajeme, in Sonora, Mexico, specifically its strategic, key, and support processes. The typology of companies that participated in the study were chosen for convenience (140), and are shown in Table 1.

Table 1. Sample of the companies that participated in the study

\begin{tabular}{|c|c|}
\hline Type & Companies (\%) \\
\hline Food and beverage preparation & 53 \\
\hline Sale/rental and maintenance of equipment and furniture & 25 \\
\hline Advertising and related activities & 8 \\
\hline Cleaning & 5 \\
\hline Transport & 5 \\
\hline Elementary education & 3 \\
\hline Leisure services & 3 \\
\hline Total & $\mathbf{1 0 0}$ \\
\hline
\end{tabular}

For this project, the quota sampling technique was used, due to the nature of the selection of the subjects to be studied, from which a minimum quota of 30 units are required. The selection of the study subjects was made from a population of companies that had been studied at length as part of the 
teaching strategy of some courses in the Industrial and Systems Engineering degree offered at the Technological Institute of Sonora.

\section{Instrument}

The rubric-type instruments proposed by Arellano-González, Carballo-Mendívil, and Ríos-Vázquez (2017) were used to measure the maturity level in the eleven processes identified in the ADOES model, classified as strategic, key, key support, and administrative support. The criteria evaluated by the Instruments are presented:

1. Strategic

- Managing the organization: decision making (planning), resource allocation (organization), leadership (management), and measurement and control system.

- Formulate a strategic plan: formulation of the organizational philosophy, analysis of the organizational environment, establishment of strategic objectives, and deployment of the strategic plan.

- Manage the quality system: focus on the customer, staff commitment to quality, focus of processes, organizational improvement, and external relations management.

\section{Key}

- Plan service delivery: preparation for formulating plans, formulating plans, and improving plans.

- Market and sell: marketing, negotiation with buyers, and evaluation of marketing.

- Deliver the service/operations: preparation for service delivery, development of operations, service delivery, and evaluation and improvement of services.

- Manage customer service: customer involvement, after-sales contact, and evaluation of service.

3. Key support:

- Develop R\&D: design of new services, design capabilities, and improvement of the design process.

- Supply and manage inventories: planning the purchasing process, materials purchasing and reception, storage, system for inventory control and movement of materials, evaluation and selection of suppliers, and evaluation and improvement of purchases.

- Managing the infrastructure and environment: maintaining the installations, the internal physical environment, and the means of transport.

4. Administrative support: Managing resources: material, human, technological, and financial. 
According to the reliability study carried out (see Table 2), these instruments are trustworthy, i.e., similar results are obtained when applying them several times to the same group.

Table 2. Reliability study of the instruments

\begin{tabular}{|c|c|c|c|c|}
\hline $\begin{array}{c}\text { Instrument / } \\
\text { Type of process }\end{array}$ & $\begin{array}{c}\text { Total } \\
\text { items }\end{array}$ & Cronbach's alpha & Average & Variance \\
\hline 1. Strategic & 30 & 0.896 & 2.811 & 0.091 \\
\hline 2. Key & 31 & 0.884 & 2.928 & 0.119 \\
\hline 3. Key support & 30 & 0.883 & 2.773 & 0.159 \\
\hline 4. Administrative support & 13 & 0.775 & 3.038 & 0.075 \\
\hline
\end{tabular}

Reliability was determined using Cronbach's alpha; according to Camacho (2005) the closer the alpha value is to 1 , the greater the internal consistency of the analyzed items. For example, George and Mallery (2003) consider a coefficient greater than 0.7 to be acceptable, and greater than 0.8 to be good.

\section{Procedure}

After carrying out the field work to gather information from the companies applying the instruments, the data were processed on spreadsheets, determining the percentage of compliance with each process with respect to the reference model, applying the following formula:

$\%$ of process compliance

$$
=\frac{\mathrm{M} 1+0.9 \mathrm{M} 2+0.84 \mathrm{D} 1+0.7 \mathrm{D} 2+0.61 \mathrm{C} 1+0.45 \mathrm{C} 2+0.32 \mathrm{I} 1+0.15 \mathrm{I} 2}{\text { (total of Instrument items }-\mathrm{NA})} * 100
$$

Where M=Mature; $\mathrm{D}=$ Developing, $\mathrm{C}=$ Craft-like, I=Incipient, and $\mathrm{NA}=$ not applicable. The values M1, D1, C1, and I1 correspond to the sum of the answers where the situation of the companies were completely in line with the case established in the rubric, and the values M2, D2, C2, and I2 for those questions whose answers indicated that the company only complied partially with the approach.

To obtain overall total compliance with the processes, the average was considered. Likewise, the compliance level of each section of the processes was calculated.

Thus, with the overall compliance percentage calculated, and for each process and process section, they were then qualitatively evaluated, considering the following maturity scale: Mature for those that complied with 85-100\%, in Development for those cases with a value between 62 and $84 \%$, Craft-like for values of 33-61\%, and Incipient for 0-32\%.

To represent those results, graphs were generated to represent the maturity profile for each type of organization process, generally where the information is taken with respect to the compliance level of each type of process and specifically with the data by process section. 


\section{Results}

In general terms, the service sector companies in the municipality of Cajeme have similar characteristics with respect to the maturity level of their organizational processes. It was detected that $75 \%$ of the companies analyzed within the service sector have a maturity level that is "Craft-like," and only 25\% are "Developing". This indicates that the majority of the companies fulfill basically half of the ideal established by the ADOES model.

On an individual basis, the level of each type of organizational process in the service sector can be seen in Figure 3. On the strategic level, the results indicate that the majority of the companies have an area of opportunity for organizational direction and governance regarding organizational management, strategic planning, and quality management. At the Key level, it can be seen that the majority of the companies have a large area of opportunity with regard to the competencies that make them unique as an organization in the activities of service delivery, marketing, and customer service. As for the administrative support process, nearly half of the companies have an area of opportunity concerning processes with internal customers in the areas of $R \& D$, inventory management, and infrastructure management. In terms of administrative support, it can be concluded that the majority of the companies have an area of opportunity in processes with internal clients in the areas of human, financial, and technological resource management.

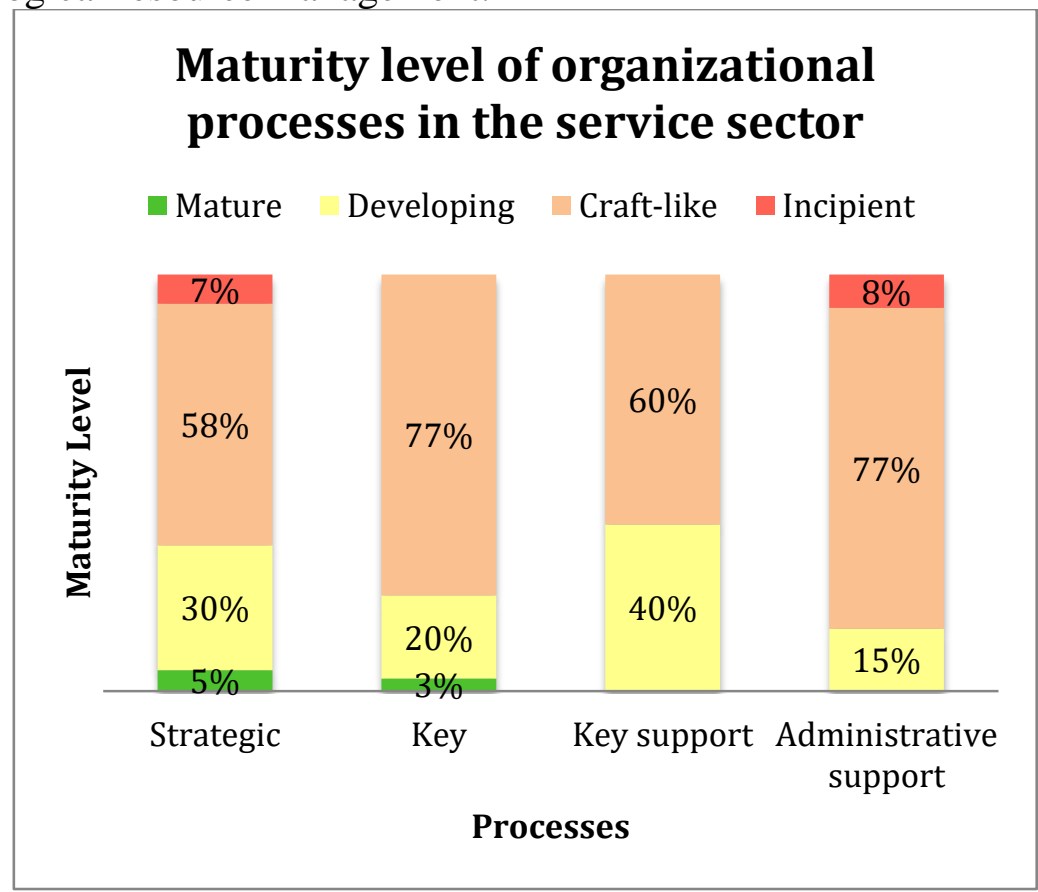

Figure 3. Maturity level of organizational processes in the service sector. 
Particularly with respect to strategic processes, a "Craft-like" maturity level was found, with a 58\% average compliance with the ideal established in the ADOES model. Figure 4 shows the maturity level of the strategic processes, where the detail of the maturity level of each evaluated process can be seen.

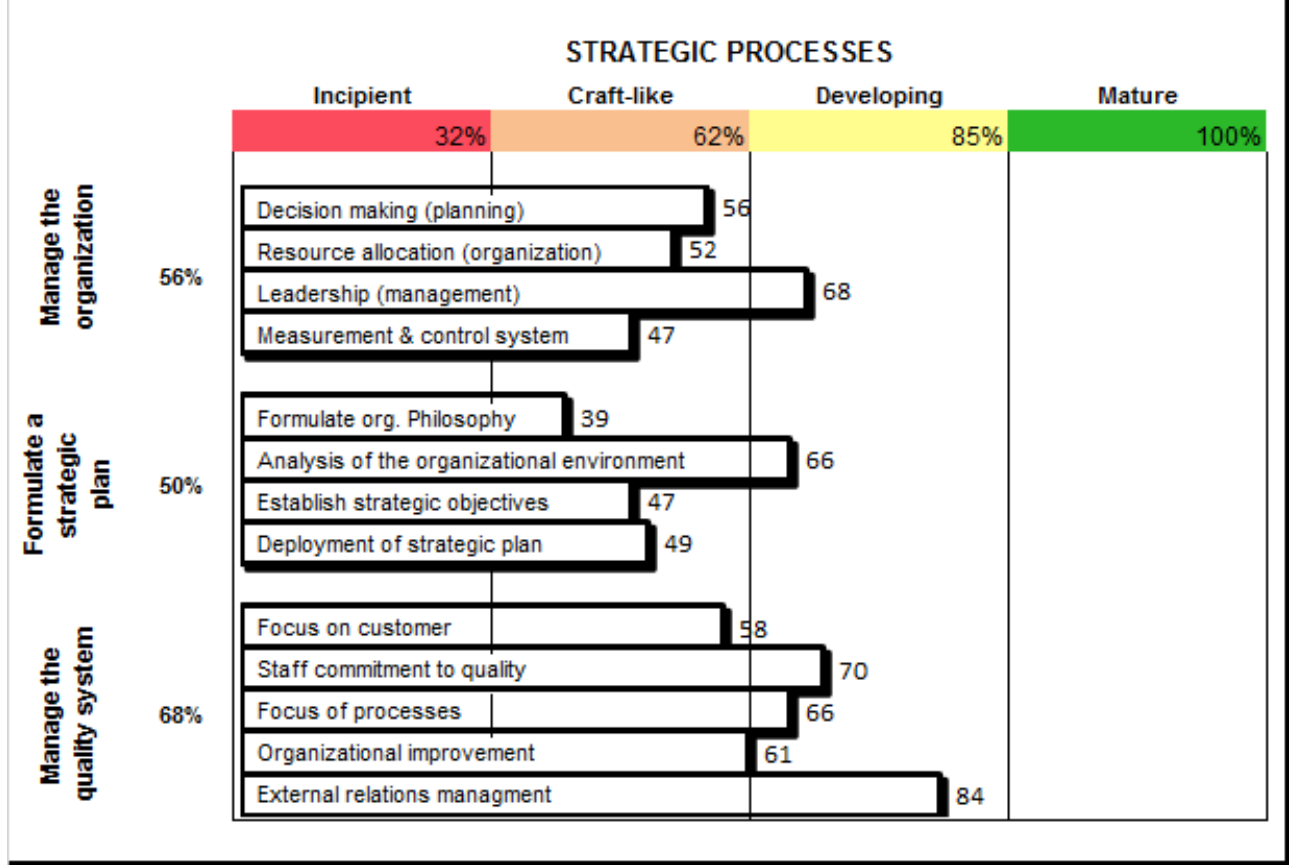

Figure 4. Compliance level of the strategic processes.

The process of organizational management complies with $56 \%$ of the ideal, placing it in the second maturity level, called "Craft-like," because when making decisions, the owners base their plans on past experience, without a point of comparison. They do not consider it important to communicate their plans to all staff, and they do not take the need for alternative plans into account. The allocation of human resources is carried out based on availability and level, and the material according to what will be needed for the current operation. With respect to leadership, which has a maturity level of "Developing," a democratic leadership style is observed, looking out for employees and taking their opinions into account, although the established mission and values are not considered when making decisions. Additionally, the measurement and control systems are scarce; the staff itself notifies of product availability and service quality, and unforeseen situations are dealt with before they seriously affect the organization.

The process of Formulating a strategic plan is also categorized at the Craft-like level, given that the average is $50 \%$. It can be seen that with respect to the formulation of the organizational philosophy, the mission and 
vision are established and revised very sporadically. As regards the organizational environment analysis, which has a maturity level of "Developing," it is carried out periodically to base decision making on external information obtained, although it is neither a fixed nor a constant procedure, and periodic meetings are held with the staff and operators to receive feedback about complaints and suggestions, sometimes completing non-standardized reports by hand. Moreover, the objectives are established by the owners and management, but these are related only to income and customer satisfaction. Finally, deployment of the plan is carried out by giving partial instructions not integrated into the general plan, with the result that the employees know what they have to do, but not why.

Finally, the third strategic process, called Managing the quality system, is at the maturity level of "Developing," with an average of 68\%, although the focus on the client is Craft-like, because requests, needs, and suggestions do not always reach the higher levels where the decisions are made. However, a certain degree of commitment to quality can be seen, as the manager regularly speaks with the operators to remind them of the importance of quality and customer satisfaction, the focus of the processes is clear, as the operating processes have been detailed on flow charts, where the work of each employee is identified as input that another process requires to be completed. Nevertheless, organizational improvement is at a lower level, due to the processes not being fully documented, which hinders data collection for real time follow-up. Lastly, for External relations management, only long- and medium-term relationships with customers and suppliers in an environment of trust and mutual respect are considered important.

Figure 5 presents the detailed result of the Key process analysis, where a "Craft-like" maturity level was also found, with a 53\% average compliance with the ideal established in the ADOES model.

The process of Planning service delivery received a maturity level of "Craft-like" with a compliance of $48 \%$, since when preparing to formulate the plan, only invoices or receipts are used to register sales, providing only a partial idea of the installed capacity of the organization and the owners have the final word with respect to the service to be offered. The formulation of plans is carried out based on experience and is informal, as there are no historical records to support the activity, and therefore, the improvement of plans cannot truly be carried out, but rather reactive measures.

In the next process, Marketing and Selling, a "Craft-like" level was also found, with $56 \%$ of compliance, since for marketing, companies only stay up to date with respect to the needs of the market when the salespeople take complaints and suggestions to the owners when there are serious problems with the product, and the marketing channels are their webpage or flyers. However, negotiation with buyers resulted in a maturity level of 
"Developing," as discounts and payment facilities to other organizations that are customers of the services provided are tabulated. Nevertheless, to evaluate marketing, only information about the effectiveness of the sales strategies based on informal information captured by operators is gathered and the customers are heard only after delivery of the service through opinion questions and/or a complaint and suggestion box.

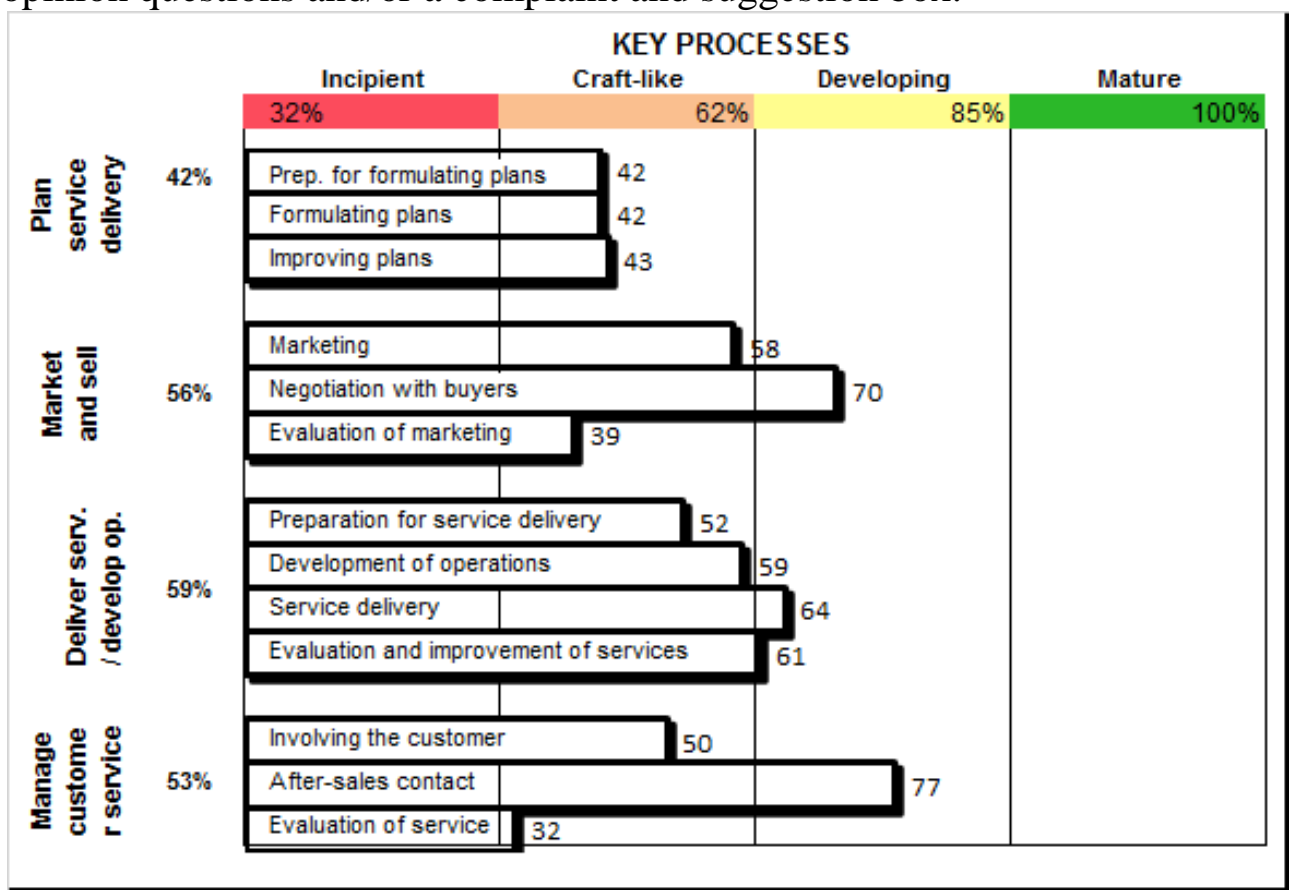

Figure 5. Compliance level of the key processes.

Source: Prepared by the authors

The process of Service delivery/operations also has a "Craft-like" level, with only $59 \%$ of compliance, since when preparing for service delivery, the entrepreneur creates the plans empirically. Operations are performed with generic procedures, but the workers are left to carry them out in the manner in which they see fit and stoppages due to equipment failure and/or lack of raw materials are common, although there is no record of how frequent these are. Nevertheless, service delivery as a "moment of truth" has a maturity level of "Developing," as the service is provided following a process that is but flexible to the customer's needs, rewarding those who work a lot and contribute to the company's results although service assessment and improvement are not at the same level. As the outcome of the service provided is not verified upon reception to make immediate corrections when necessary, there are no systematic measurements, but if necessary, certain indicators can be calculated with manually recorded data. 
Finally, the process of Managing customer service also has a "Craftlike" maturity level with a compliance rate of 53\%, since customer involvement only concerns their opinion about the quality of service and their satisfaction with same, either verbally or through the suggestion box, though the customer is offered discounts and other promotions to promote after-sales contact. Nevertheless, service assessment is "Incipient," as the operators occasionally ask the customers for their opinions, which can generate a lack of timely improvement to undesirable results.

As far as Key support processes, Figure 6 shows that these kinds of processes have a "Craft-like" maturity level, with a 56\% rate of compliance in relation to the ideal established in the reference model.

The process of Research and Development (R\&D) is classified as "Craft-like," despite the design of new services being "Developing," as new products are developed by copying what works for the competition, continuously incorporating improvements through practice. However, the capacity for design is "Incipient," given that the design of products and/or processes is based on the previous experience of the owner and is little adapted to the needs of the customer. In addition, to improve the design process, meetings are simply held with workers to hear their opinions with respect to the new process/service.

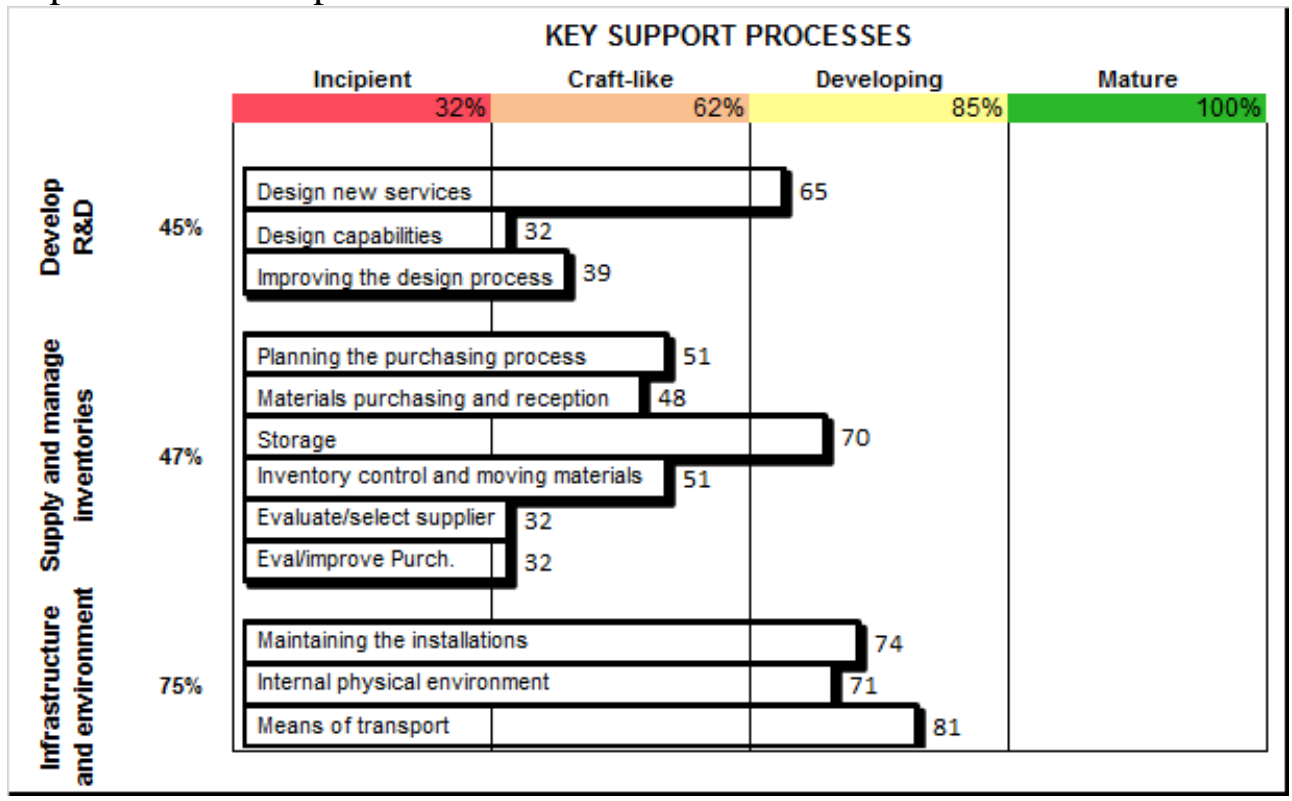

Figure 6. Compliance level of the key support processes

The process of Storing and Managing Inventories also has a "Craftlike" maturity level with a compliance rate of $47 \%$, because process planning is carried out based only on experience, which causes problems such as shortages or emergency purchases. For execution of purchases and reception 
of materials, only a visual and random physical verification is performed, with specifications indicated verbally. However, storage is "Developing," since there is an assigned space for every type of product in the warehouse and materials that move more quickly are placed in special areas, although time is occasionally wasted searching for them. In spite of this, the inventory control system is very basic, which is evident in the frequent inconsistencies in the system. In addition, evaluation and selection of suppliers is "Incipient," as there is no formally established process to evaluate themthey are chosen by geographic proximity, price, and payment terms, among other basic indicators. Likewise, evaluation and improvement in purchasing is another area of opportunity in the sector, since it is rarely analyzed, except when an evident and alarming problem arises.

The process of Managing Infrastructure and Environment complies with $75 \%$ of that considered ideal, placing it at a maturity level of "Developing," since maintenance of the installations allows avoiding interruptions to operations. The internal physical environment remains in good conditions as the same importance is given to the appearance of the installations as to the service offered to the customer, and because the means of transport have been adapted to facilitate the delivery of merchandise and/or service, and are used appropriately by the delivery person.

Finally, Figure 7 shows the results of the Administrative support process, which obtained a 45\% compliance rate with respect to the ideal, placing it at a "Craft-like" maturity level.

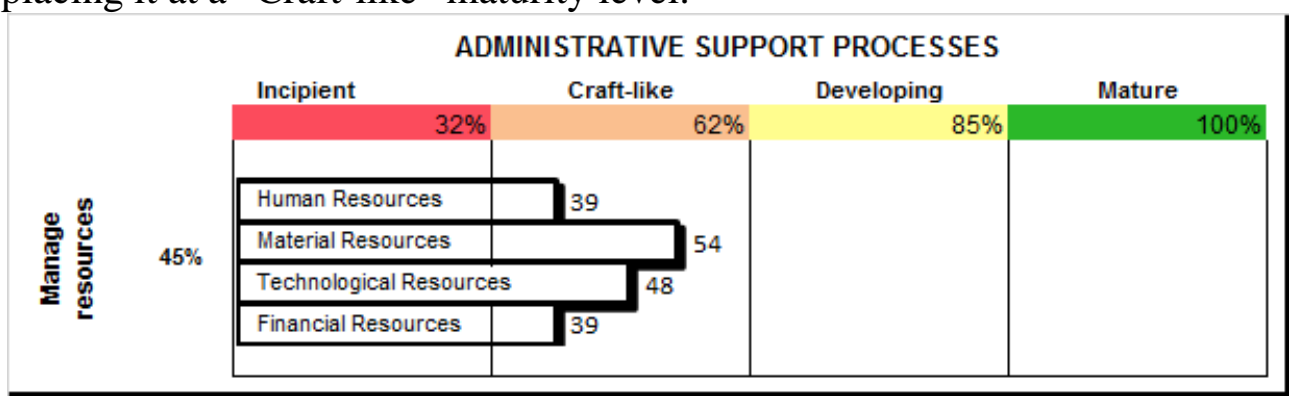

Figure 7. Compliance level of the administrative support processes

In the final process of Managing resources, it can be seen that a traditional pyramidal organigram has been created and people are hired through advertisements and employee recommendation; staff training is considered important, but not enough financial resources are earmarked for it, although efforts are made to measure employee performance based on established goals. Furthermore, for material resources, there is only a record of critical materials to avoid shortages, and the rest is only purchased when supplies are depleted, without generating any statistics from the obtained results. With respect to technological resources, basic information systems 
are used to support the business’ critical activities, such as inventory control and invoicing, among others, and there is an Internet connection to access the information and administrate the webpage.

As to Financial resources, efforts are underway to incorporate trusted minority partners, but without giving up control, and to eventually take out loans when it is inevitable to finance the company's operations.

\section{Discussion}

The results obtained in this project concur with the findings of other research carried out on SMEs. As mentioned in the research carried out by the PYMES-Cumex Network (SME Network-Consortium for Mexican Universities) (2010), Sonoran entrepreneurs today have an average of 10 years of experience, and of those who had experience running a business before their current activities: $81 \%$ had had 1 to 2 businesses, and the remaining between 3 and 6 . In the urban area of Cajeme, 39\% of entrepreneurs have more than 16 years of experience, which could give the impression that their businesses have a high maturity level; however, the results of this investigation show that on average, companies maintain a maturity level of Craft-like, i.e., despite having general knowledge of the continuous improvement approach and sporadically implementing improvement activities, they have yet to formalize or systemize in order to self-regulate and achieve consistent results.

In terms of the Strategic processes, there is a notable absence of Strategic plans. The short-term management is mostly carried out by the company's owner, and the commitment to comprehensive quality is low, which corresponds to the results of the research from the PYMES-Cumex Network (2010) and Landázuri-Aguilera, et al. (2013) who indicate that only $38 \%$ of Sonoran companies have documented plans and in the urban area of Cajeme this percentage drops to $31 \%$. 21\% do not have a formal structure of their organization represented in an organization chart where the positions and lines of authority are acknowledged, implying that there are basic problems related to organizational management and leadership, and that although it was detected that $27 \%$ of the state enterprises use quality improvement techniques, only 19\% of companies have been quality certified. Therefore, based on the conducted research, it can be assumed that in Cajeme, and when it takes place, planning is reactive, centered basically on investments in infrastructure to attend to the apparent increased demand, but not backed by any deep analysis of facts and data; and that quality techniques are precariously involved in operating processes, and not for decision-making that would give way to a more comprehensive improvement in organizational performance. 
In relation to Key processes, a correlation was detected with the aforementioned research with respect to the lack of strategic vision and comprehensive organizational management, since operational planning is carried out empirically - there are practically no documented procedures in terms of operations; and regarding marketing, there is basically only one mechanism to attend to the customer's complaints, and advertising carried out through flyers and webpages, in spite of the importance of offering their products or services according to the needs expressed by the consumers. This coincides with the data reported by the PYMES-Cumex Network (2010), which indicates that less than half of Sonoran companies document their procedure; and although $28 \%$ do use market research techniques, only $5 \%$ consider it important to conduct it with a focus on competition; likewise, an average of $53.4 \%$ advertise to receive a direct response from the consumer, which they consider to have contributed in reaching sales goals.

In the process considered as Key support in service businesses, the process of supply and inventory management has been detected to maintain the same characteristic as the remaining processes related to empirical planning, i.e., not based on historical data of material consumption for estimations with forecasts of future demand. Likewise, innovation is one of the least mature processes, which coincides with the report of the PYMESCumex Network (2010), which indicates that less than half of the companies consider innovation important in service or the end product that they deliver to their customers. Nevertheless, infrastructure management is the process with the highest maturity level, which is Developing - understandable, since the companies are in the service sector, where part of the value that they offer customers is in the environment in which they provide said services and other related intangible aspects.

Finally, as far as the Administrative support of resource management processes, the research findings report that some entrepreneurs have trusted minority partners, but do not give up control, and eventually take out loans in banking institutions. This is also reported by the PYMES-Cumex Network (2010), which indicates that the resources they manage come from their savings in $85 \%$ of cases and when external resources are used, half come from family and friends and the other half from financial institutions.

In addition, regarding people management, it has been detected as very basic, and even informal. For example, recruitment is done through advertisements and recommendations from other employees, and little investment is made toward their development, although their training is considered important. This coincides with the results of the research of the PYMES-Cumex Network (2010), where it is reported that small business owners consider it unnecessary or of little importance to offer training courses, although they do place value on marketing, promotion, advertising, 
and sales, as well as customer service, thus showing interest in serving an ever more competitive market, although not in issues such as language acquisition and foreign trade, since their primary focus is on the local market. Likewise, it is reported that more than a third never or rarely conduct human resources practices, representing a great disadvantage of not having the ideal selection of personnel and methods that allow motivation and development of same.

Furthermore, in the area of technology, it was found that information systems are simple and used basically for communication and not as much to support the business' critical activities, which coincides with the report of the PYMES-Cumex Network (2010), which indicates that the businesses use predominantly traditional communication methods, such as telephone and fax, although 60\% also make use of email and the internet, which is a mandatory tool nowadays to support business competition. However, 90\% do have accounting information systems that allow them to fulfill their tax requirements.

\section{Conclusion}

The proposed objective of the project here reported was to determine the maturity level of small enterprises in the service sector in Cajeme, which play a leading role in the economy of the region, due as much to the number of people working in them as to the contribution to the city's total income.

The service sector has increased its participation in the economy of all countries and will likely continue doing so, which indicates the importance of having proper knowledge of the same for the people that depend upon it directly.

It is important to understand the definition of a service business, as in practice, there tends to be confusion between the service and transformation sectors, due to their similarities.

In general terms, it can be deduced that businesses in the service sector in the municipality of Cajeme are no older than 5 years, as they are at a "Craft-like" maturity level and the improvement process of their operations is dependent on how long they have been offering their services in the market.

In conclusion, $75 \%$ of the businesses that were analyzed in the service sector in the municipality of Cajeme have a "Craft-like" maturity level (compliance rate between 33 and 61\%), and only 25\% are "Developing" (62-84\%), indicating that the Strategic processes are carried out based on the owner's experience and with a short-term outlook, instead of using a formal long-term planning, monitoring, and control system. The Key processes are neither documented nor standardized, and therefore there is variation in results. The Key support processes do not consistently support 
the Key processes, which could result in undesirable situations along the way, causing idleness and delays. Finally, the Administrative support processes are managed based on cost rather than quality and functionality, having a direct impact on customer satisfaction.

The main contribution of this work was defining the service sector in a city in Mexico, which will help entrepreneurs in the sector to better know the area in which they operate, researchers to have the micro and small business sector as a subject of study to make more contributions to this important and complex service sector, and the government (specifically the Secretariat of Economy) to have more information with respect to the companies that operate in the region.

\section{Funding:}

This publication was funded with PFCE 2016 and PROFAPI 2017 resources.

\section{Acknowledgements}

We also express our gratitude for the support from the National Laboratory in Transportation Systems and Logistics (SiT-LOG Lab)), ITSON chapter, supported by the National Council of Science and Technology of México (CONACYT) and the Mexican Institute of Transport (IMT), as well as from the Mexican Logistics \& Supply Chain Association (AML).

\section{References:}

1. Adizes, I. (1994). Ciclos de vida de la organización: cómo y por qué crecen y mueren las organizaciones y qué hacer al respecto. Madrid, España: Ediciones Díaz de Santos.

2. Arellano-González, A., Carballo-Mendívil, B., \& Ríos-Vázquez, N. J. (2017). Análisis y diseño de procesos. Una metodología con enfoque de organizational maturity. México: Pearson Educación.

3. Arellano-González, A., Carballo-Mendívil, B., Orrantia-López, M., \& Salazar-Rivera, R. (2013). Diagnóstico de la madurez de los procesos de la cadena de valor de una pequeña empresa mexicana de productos de maíz. Pensamiento \& Gestión, 1(34), 122-136.

4. Brookes, N., Butler, M., Dey, P., \& Clark, R. (2014). The use of maturity models in improving project management performance: An empirical investigation. International Journal of Managing Projects in Business, 7 (2), 231-246.

5. Butzer, S., Schötz, S., \& Steinhilper, R. (2017). Remanufacturing Process Capability Maturity Model. Procedia Manufacturing, 8, 715722. 
6. Camacho, J. (2005). Estadística con SPSS para Windows. España: RA-MA Editorial.

7. Carroll, N., \& Helfert, M. (2015). Service capabilities within open innovation: Revisiting the applicability of capability maturity models. Journal of Enterprise Information Management, 28 (2), 275-303.

8. Diario Oficial de la Federación - DOF . (30 de Junio de 2009). Acuerdo por el que se establece la estratificación de las micro, pequeñas y medianas empresas. Obtenido de Sitio web del DOF: http://www.dof.gob.mx/nota_detalle.php?codigo=5096849\&fecha $=3$ 0/06/2009

9. Domingues, P., Sampaio, P., \& Arezes, P. M. (2016). Integrated management systems assessment: a maturity model proposal. Journal of Cleaner Production, 124, 164-174.

10. European Foundation for Quality Management - EFQM. (2012). The EFQM Excellence Model. Obtenido de Página web del EFQM: http://www.efqm.org/the-efqm-excellence-model

11. George, D., \& Mallery, P. (2003). SPSS for Windows step by step: A Simple Guide and Reference. 11.0 Update (4a ed.). Boston: Allyn \& Bacon.

12. González-Solá, A., M. d., \& Vilalta-Alonso, J. A. (2007). La autoevaluación como herramienta para gestionar la calidad en pequeñas y medianas empresas con un destino turístico: una experiencia cubana. Ingeniería Industrial, XXVIII(2), 38-41.

13. Hammer, M. (Abril de 2007). La auditoría de proceso. Harvard Business Review, 92-104.

14. Instituto Nacional de Estadística y Geografía - INEGI). (2014). Investigación. Esperanza de vida de los negocios en México. Obtenido de Sitio web del INEGI: http://www.inegi.org.mx/inegi/contenidos/Investigacion/Experimenta les/esperanza/default.aspx

15. Instituto Nacional de Geografía y Estadística - INEGI. (2014). Censo económico 2014. Resultados definitivos. Obtenido de Sitio web del INEGI:

http://www.inegi.org.mx/est/contenidos/proyectos/ce/ce2014/default. aspx

16. International Organization for Standardization. (2009). Norma ISO 9004. Gestión para el desarrollo sostenido de una organización Enfoque de gestión de calidad. Ginebra, Suiza: International Organization for Standardization.

17. International Organization for Standardization. (2015). Sistema de gestión de calidad - Requisitos. Ginebra, Suiza: International Organization for Standardization. 
18. Kosieradzka, A. (2017). Maturity Model for Production Management. Procedia Engineering, 182, 342-349.

19. Landázuri-Aguilera, Y., Chávez-Rivera, M., \& Ochoa-Jaime, B. (2013). Perfil administrativo y financiero de las micro y pequeñas empresas en el municipio de Cajeme, Sonora. Universidad Nacional Autónoma de México. México: Congreso Internacional de Contaduría, Administración e Informática.

20. Montaño-Arango, O. (2012). Evolución de Modelos que identifican la madurez de los procesos. DYNA , 87 (2), 132-133.

21. Montaño-Arango, O., Corona-Armenta, J. R., Pérez-Rojas, A., \& Medina-Marin, J. (2010). Modelo que identifica la madurez de los procesos. Caso: pequeña empresa manufacturera. Dyna, 85(5), 392400.

22. Mullaly, M. (2014). If maturity is the answer, then exactly what was the question?, International Journal of Managing Projects in Business , 7 (2), 169-185.

23. Parra, C. M., Villa, V. M., \& Restrepo, J. W. (Julio de 2009). Gestión de la calidad con el modelo EFQM en 10 empresas metalmecánicas de Medellín. Revista EIA (Escuela de Ingeniería de Antioquía)(11), 9-19.

24. Porter, M. E. (2005). Ventaja Competitiva. Creación y Sostenimiento de un Desempeño Superior. España: Alay Ediciones, S.L. (Grupo patria cultural).

25. Proença, D., \& Borbinha, J. (2016). Maturity Models for Information Systems - A State of the Art. Procedia Computer Science, 100, 10421049.

26. Red PYMES-Cumex. (Enero-junio de 2010). Un estudio comparativo del perfil financiero y administrativo de las pequeñas empresas en México: entidades del estado de México, Hidalgo, Puebla, Sonora y Tamaulipas. Resultados finales. Revista del Centro de Investigación Universidad La Salle, 9(33), 5-30.

27. Röglinger, M., Pöppelbuß, J., \& Becker, J. (2012). Maturity models in business process management, Business Process Management Journal, 18 (2), 328-346, doi.org/10.1108/14637151211225225

28. Rohvein, C., Paravie, D., Urrutia, S., Roark, G., Nunes, D., \& Ottogalli, D. (Enero-junio de 2013). Metodología de evaluación del nivel de competitividad de las PYMES. Revista Ciencias Estratégicas, 21(29), 49-68.

29. Software Engineering Institute. (2010). CMMI for Services, Version 1.3. Hanscom, USA: Carnegie Mellon University.

30. Supply Chain Council. (2010). Supply Chain Operations Reference (SCOR $\left.{ }^{\circledR}\right)$ model, Inc. Cypress, Texas, Estados Unidos. 
31. Tarhan, A., Turetken, O., \& Reijers, H. A. (2016). Business process maturity models: A systematic literature review. Information and Software Technology, 122-134.

32. Tarí-Guilló, J. J., López-Gamero, M. D., \& Molina-Azorín, J. F. (2007). El proceso de autoevaluación según el modelo EFQM. Investigaciones Europeas de Dirección y Economía de la Empresa, 13(2), 203-216.

33. Uskarc1, A., \& Demirörs, O. (2017). Do staged maturity models result in organization-wide continuous process improvement? Insight from employees. Computer Standards \& Interfaces, 52, 25-40.

34. von Scheel, H., von Rosing, G., Skurzak, K., \& Hove, M. (2015). BPM and Maturity Models. En M. von Rosing, A.-W. Scheer, \& H. von Scheel, The Complete Business Process Handbook. Body of Knowledge from Process Modeling to BPM, (Vol. I, págs. 395-426). USA: Morgan Kaufmann Publishers.

35. World Bank Group. (2016). World Development Indicators. Washington DC: International Bank for Reconstruction and Development/The World Bank. 